Journal Indonesian Language Education and Literature Vol.1, No. 2, 2016

http://www.syekhnurjati.ac.id/jurnal/index.php/jeill/

\title{
TEORI KONEKSIONISME DALAM PEMBELAJARAN BAHASA KEDUA ANAK USIA DINI
}

\author{
Mohamad Ali Zahidin, Indrya Mulyaningsih \\ IAIN Syekh Nurjati, Cirebon \\ zahidinali5@gmail.com
}

\begin{abstract}
Abstrak
Teori koneksionisme memandang bahwa belajar itu terjadi dengan cara mencobacoba dan membuat salah, demikian juga pada pembelajaran bahasa pada anak usia dini. Setiap anak usia dini pada awalnya melakukan percobaaan berbahasa dan membuat kesalahan-kesalahan melafalkan sebelum akhirnya menjadi terbiasa dan benar sehingga menambah kosa-kata bahasa yang pada ahirnya dapat memudahkan dalam menyampaikan maksud dan tujuan kepada lawan bicaranya. Proses tersebut dapat dilihat dari proses pembelajaran bahasa kedua pada anak usia dini. Pada pembelajaran bahasa kedua yang dilakukan oleh anak usia dini menunjukan kesesuaian hukum dan prinsip belajar teori Koneksionisme. Pemberian hadiah menjadi stimulus anak-anak untuk belajar dan motivasi untuk melafalkan kata yang diajukan sebagai bentuk respon yang positif. Berkurangnya jumlah rata-rata pengulangan dari minggu pertama sebanyak tujuh belas kali menjadi tiga kali pada minggu keempat merupakan bukti prinsip belajar trial and error yang dikemukakan oleh Edward Thorndike. Faktor pembelajaran bahasa kedua sangat dipengaruhi oleh umur, bahasa pertama, perkembangan bahasa dan motivasi.
\end{abstract}

Kata kunci : koneksionisme, lafal, usia dini

Connectionism theory view that learning occurs by experimenting and making mistakes, as well as language learning in early childhood. Each early childhood initially tries to speak and make mistakes before they become accustomed to the pronunciation and correct. Any child's vocabulary has increased and finally to convey the intent and purpose to his interlocutor well. The process can be seen from the process of learning a second language in early childhood. In second language learning is done by younger children show conformity of laws and principles of learning connectionism theory. Giving the prize being a stimulus of children to learn and motivated to recite the words proposed as a form of positive response. Reduced average number of repetitions of the first week as many as seventeen times to three times in the fourth week is a proof of principle trial and error learning proposed by Edward Thorndike. Factors second language learning is strongly influenced by age, first language, language development and motivation.

Keyword: connectionism, pronounciation, early childhood 


\section{A. Pendahuluan}

Teori Koneksionisme merupakan salah satu teori belajar yang menjelaskan proses pembelajaran yang di alami oleh individu. Teori Koneksionisme memandang bahwa belajar itu terjadi dengan cara mencobacoba dan membuat salah, demikian juga pada pembelajaran bahasa pada anak usia dini. Setiap anak usia dini pada awalnya melakukan percobaaan berbahasa dan membuat kesalahan-kesalahan melafalkan sebelum akhirnya menjadi terbiasa dan benar sehingga menambah kosa-kata bahasa yang pada ahirnya dapat memudahkan dalam menyampaikan maksud dan tujuan kepada lawan bicaranya.

Terlepas dari asal usul bahasa manusia itu, apakah karena alami (fisis) ada pada manusia atau karena sebuah kesepakatan bersama antar pemakai bahasa (konvensi).Manusia pada umumnya pasti melewati sebuah proses pembelajaran dalam hal apapun, baik secara sadar atau tidak sadar sejak ia dilahirkan. Termasuk di dalamnya yaitu dalam mempelajari bahasa verbal sebagai penyampai pesan maksud dan tujuannya kepada orang lain. Anak usia dini merupakan tahap awal bagaimana ia belajar berbicara dan belajar berbahasa.

Merunut dari fakta sejarah membuktikan bahwasannya manusia selalu mengalami perkembangan yang sangat pesat dan kompleks, baik secara pemikiran dan prilaku dari masa ke masa untuk menyesuaikan diri dengan lingkungannya dalam rangka bertahan hidup. Dinamisme yang sangat cepat dan kompleks tersebut tentunyamerubah pola pikir, prilaku dan segala bentuk kegiatannya. Tidak terkecuali, prinsip dan hukum teori belajar Koneksionismeyang telah di rumuskanberdasarkan hasil penelitian pada tahun 1980 silam oleh Edwar Thorndike. Menghitung waktu dirumuskan dengan masa sekarang sangat memungkinkan terjadinya perubahan di berbagai sisi. Penelitian yang di lakukan secara berkala merupakan salah satu upaya menjawab kenyataan tersebut, disamping menjadikan lebih memahami proses bagaimana pembelajaran bahasa pada anak usia dinisekaligus juga sebagai pembuktian teori belajar Koneksionisme. 
Berdasarkan latar belakang masalah diatas dapat diketahui rumusan masalahnya yaitu bagaimana teori belajar Koneksionisme menjelaskan proses pembelajaran bahasa pada anak usia dini.

\section{Teori Belajar Koneksionisme}

Teori Koneksionisme pertama kali dicetuskan oleh Edward Thorndike yaitu seorang pendidik dan psikolog yang berkebangsaan Amerika. Menurut Thorndike, belajar merupakan peristiwa terbentuknya asosiasi-asosiasi antara peristiwa-peristiwa yang disebut Stimulus (S) dengan Respon (R). Stimulus adalah suatu perubahan dari lingkungan eksternal yang menjadi tanda untuk mengaktifkan organisme untuk beraksi atau berbuat sedangkan respon adalah sembarang tingkah laku yang dimunculkan karena adanya perangsang.

Dari hasil percobaan yang dilakukan Thorndike pada seekor kucing. Thorndike merumuskan hukum-hukum sebagai berikut:

\section{a. Law of Readiness (Hukum Kesiapan)}

Ketika seseorang dipersiapkan (sehingga siap) untuk bertindak, maka melakukan tindakan merupakan imbalan (reward) sementara tidak melakukannya merupakan hukuman (punishment) (Schunk: 2012). Semakin siap suatu individu terhadap suatu tindakan, maka perilaku-perilaku yang mendukung akan menghasilkan imbalan (memuaskan). Kegiatan belajar dapat berlangsung secara efisien bila si pelajar telah memiliki kesiapan belajar. Ada tiga keadaan yang menunjukkan berlakunya hukum kesiapan ini, yaitu bahwa:

1) Apabila suatu unit tingkah laku telah siap digunakan, maka penggunaannya akan membawa kepuasan.

2) Apabila suatu unit tingkah laku telah siap digunakan namun tidak digunakan maka akan menimbulkan ketidakpuasan (kerugian) dan menimbulkan respon yang lain untuk mengurangi atau meniadakan ketidakpuasan itu.

3) Apabila suatu unit tingkah laku belum siap tetapi dipaksakan untuk digunakan maka akibatnya juga kerugian. 


\section{b. Law of Exercise (Hukum Latihan)}

Koneksi antara kondisi dan tindakan akan menjadi kuat karena latihan dan akan menjadi lemah karena kurang latihan. Dalam belajar, pelajar perlu mengulang-ulang bahan pelajaran. Semakin sering suatu pelajaran diulangi semakin dikuasai pelajaran tersebut. Hukum ini mengandung dua hal, yaitu;

1) Law of Use (Hukum Kegunaan), sebuah respon terhadap stimulus memperkuat koneksi keduanya. Respon dalam hal ini adalah latihan tersebut.

2) Law of Disuse (Hukum Ketidakgunaan), ketika respon tidak diberikan terhadap stimulus kekuatan koneksinya menjadi menurun.

c. Law of Effect (Hukum Akibat)

Kegiatan belajar yang memberikan efek hasil belajar yang menyenangkan (hadiah) cenderung akan diulangi, sedangkan kegiatan belajar yang memberikan efek hasil belajar yang tidak menyenangkan (hukuman) akan dihentikan. Dalam pembelajaran hukum ini biasa diterapkan dengan pemberian reward and punishment.

Selain hukum dasar di atas, ada lima hukum tambahan, yaitu :

1) Hukum Reaksi Bervariasi (Multiple Respons), pada individu diawali oleh proses trial and erroryang menunjukkan adanya bermacam-macam respon sebelum memperoleh respon yang tepat dalam memecahkan masalah yang dihadapi.

2) Hukum Sikap (Attitude), perilaku belajar seseorang tidak hanya ditentukan oleh hubungan stimulus dengan respon saja tetapi juga ditentukan keadaan yang ada dalam diri individu baik kognitif, emosi, sosial, maupun psikomotor.

3) Hukum Aktivitas Berat Sebelah (Prepotency of Element), individu dalam proses belajar memberikan respon hanya pada stimulus tertentu saja sesuai dengan persepsinya terhadap keseluruhan situasi (respon selektif).

4) Hukum Respon by Analogy, individu dapat melakukan respon pada situasi yang belum pernah dialami karena individu sesungguhnya dapat menghubungkan situasi yang belum pernah dialami dengan situasi lama yang pernah dialami. 
Journal Indonesian Language Education and Literature Vol.1, No. 2, 2016

http://www.syekhnurjati.ac.id/jurnal/index.php/jeill/

\section{d. Hukum Perpindahan Asosiasi (Associative Shifting)}

Proses peralihan dari situasi yang dikenal ke situasi yang belum dikenal dilakukan secara bertahap dengan cara menambahkan sedikit demi sedikit unsur lama. Thorndike dalam teori Koneksionisme juga menyebutkan konsep transfer of training. Transfer of training yaitu hal yang didapatkan dalam belajar bisa digunakan untuk menghadapi atau memecahkan hal-hal lain yang sejenis atau berhubungan maka diperlukanlah usaha agar transfer of learning dapat terjadi secara optimal.

Selain menambahkan hukum-hukum baru, dalam perjalanan penyampaian teorinya, Thorndike mengemukakan revisi hukum belajar antara lain:

1) Hukum latihan ditinggalkan karena ditemukan pengulangan saja tidak cukup untuk memperkuat hubungan stimulus respon, sebaliknya tanpa pengulanganpun hubungan stimulus respon belum tentu diperlemah.

2) Hukum akibat direvisi, bahwa yang berakibat positif untuk perubahan tingkah laku adalah hadiah, sedangkan hukuman tidak berakibat apaapa.

3) Syarat utama terjadinya hubungan stimulus dan respon bukan kedekatan, tetapi adanya saling sesuai antara stimulus dan respon.

4) Akibat suatu perbuatan dapat menular baik pada bidang lain maupun pada individu lain (dalam: http://id.rahmanmahlil.blogspot.co.id/ teori koneksionisme).

\section{Pembelajaran dan Lafal}

Menurut Kamus Besar Bahasa Indonesia pembelajaran adalah perbuatan, perlakuan atau cara menjadikan orang atau makhluk hidup belajar dan lafaldalam Kamus Besar Bahasa Indonesia adalah ejaan, ucapan atau cara seseorang atau sekelompok orang dalam suatu masyarakat bahasa mengucapkan bunyi bahasa (dalam: http://kbbi.web.id/). 
Journal Indonesian Language Education and Literature Vol.1, No. 2, 2016

http://www.syekhnurjati.ac.id/jurnal/index.php/jeill/

\section{Pengertian Anak Usia Dini}

Anak usia dini adalah anak yang berada pada rentang usia 0-6 tahun (Undang-Undang Sisdiknas tahun 2003). Dalam pertumbuhan dan perkembangannya anak usia dini memiliki pola pertumbuhan dan perkembangan yang khusus sesuai dengan tingkat pertumbuhandanperkembangannya (Mansur,2005). Pada masa tersebut merupakan masa emas (golden age), karena anak mengalami pertumbuhan dan perkembangan yang cukup pesat dan tidak tergantikan pada masa mendatang. Menurut berbagai penelitian bidang neurologi ditemukan bahwa $50 \%$ kecerdasan anak terbentuk pada kurun waktu 4 tahun pertama. Setelah usia 8 tahun, perkembangan otaknya mencapai $80 \%$ dan $20 \%$ nya akan terjadi pada umur 18 tahun (dalam: http://ekacahyamaulidiyah.blogspot.co.idanak-usia-dini).

\section{Faktor Pembelajaran Bahasa Kedua}

Proses pemerolehan bahasa kedua dipengaruhi oleh berbagai faktor. Menurut Sri Mulyani (Mulyani \&Haryanti, 2015) terdapat lima faktor yang sangat berpengaruh dalam pemerolehan bahasa kedua. Kelima faktor tersebut adalah:

a. Faktor Motivasi

Motivasi adalah dorongan, hasrat, kemauan, alasan, atau tujuan yang hendak dicapai. Dalam proses pemerolehan bahasa kedua, motivasi dapat muncul baik secara internal ataupun eksternal yang mendorong seseorang untuk belajar bahasa kedua karena adanya hasrat, kebutuhan, harapan, dan cita-cita sehingga semakin tinggi motivasi seseorang semakin cepat dan baik pula pemerolehan bahasa keduanya.

b. Faktor Usia

Usia pada saat anak-anak dan orang dewasa sangat berpengaruh dalam pemerolehan bahasa kedua. Hal ini dkarenakan orang dewasa memiliki lebih banyak pengalamann berbahasa dan otak orang dewasa lebih berfungsisempurna dibandingkan dengan anak-anak sehingga orang dewasa lebih cepat dan banyak mendapatkan kosa kata bahasa 
keduanya. Mskipun demikian, selain faktor usia harus pula ditunjang dengan kemahiran interaksi dalam lingkungan sekitar untuk memperbanyak kosa kata bahasa secara alamiah.

\section{c. Faktor Penyajian Formal}

Pemerolehan baahasa kedua merupakan sebuah kebutuhan bagi anak ketika sedang mengikuti pendidikan di lembaga formal (sekolah). Peyajian formal yang mewajibkaan peserta didik untuk memakai bahasa Indonesia sebagai bahasa pemersatunya. Hal ini dikarenakan setiap peserta didik meiliki latar belakang yang berbeda-beda. Penyajian ini sangat ditentukan oleh guru, peranan pelajar dan peranan program belajar dalam proses pemerolehan bahasa keduanya.

d. Faktor Bahasa Pertama

Faktor bahasa pertama sangat mempengaruhi pemerolehan bahasa, hal ini dikarenakan struktur bahasa pertama menjadi jalan untuk menerjemahkan makna kata bahasa kedua. Mulyani (dalam Tarigan, 1998) mengemukakan berdasarkan penelitian pengaruh bahasa pertama terhadap pemerolehan bahasa kedua ditemukanlah sebagai berikut:

1) Bahasa pertama sangat berpengaruh terhadap susunan kata bahasa kedua dan dalam menerjamahkan frasa-frasa serta kata demi kata bahasa kedua.

2) Morfologi terikat lebih kuat daripada pengaruh bahasa pertama.

3) Pengaruh bahasa pertama sangat kuat dan besar dalam lingkunganlingkungan pemerolehan rendah atau acquisition poor.

e. Faktor Lingkungan

Faktor lingkungan adalah hal yang paling berpengaruh terhadap pemerolehan bahasa kedua, karena semua aspek dalam kehidupan faktor lingkungan sangat berperan aktif. Lingkungan terbagi dua yaitu: lingkungan formal dan lingkungan nonformal. Dalam hal ini lingkungan nonformal lebih efektif dalam proses pemerolehan bahasa kedua, karena lingkungan nonformal menyediakan ruang, tempat dan waktu yang tidak terbatas untuk berinteraksi sosial. 
Journal Indonesian Language Education and Literature Vol.1, No. 2, 2016 http://www.syekhnurjati.ac.id/jurnal/index.php/jeill/

\section{Teori Perkembangan Bahasa Anak}

Salah satu aspek dalam kajian ilmu psikologi perkembangan anak adalah aspek perkembangan bahasa. Dariyo (dalam Marat, 2005) menyebutkan ada tiga tahap perkembangan bahasa pada anak usia lima tahun pertama yaitu: 1. periodelingual, 2. periode lingual dini, 3. periode diferensiasi.

a. Periode Prelingual (Usia 0-1 Tahun)

Tahap ini ditandai dengan kemampuan bayi untuk mengoceh sebagai cara berkomunikasi dengan orang-tuanya. Bayi hanya bersikap pasif untuk menerima stimulus eksternal dari orang-tuanya. Tahap ini bayi akan memberikan respons negatif terhadap orang yang dianggap tidak ramah dan memberikan respons positif terhadap orang yang ramah.

b. Periode Lingual Dini ( Usia 1-2,5 Tahun)

Periode perkembangan bahasanya ditandai dengan kemampuan anak untuk membuat satu kata atau dua kata dalam suatu percakapan dengan orang lain. Pada tahap ini dibagi tiga tahap, yaitu:

1) Periode Kalimat Satu Kata (holophrase)

Periode kalimat satu kata yaitu kemampuan anak membuat kalimat yang hanya terdiri dari satu kata yang mengandung pengertian secara utuh ketika bicara. Misalnya: anak mengatakan "mamah”. Hal ini dapat bermakna: "Mamah saya lapar", "Mamah kesini”, "Mamah tolong saya" dan lain-lain.

2) Periode Dua Kata

Periode perkembangan bahasa yang ditandai dengan kemampuan anak membuat kalimat dua kata sebagai interaksi sosial. Misalnya: anak mengatakan: mamah bangun, ini ibu, itu papah.

3) Periode Dua Kata Lebih

Periode perkembangan bahasa yang ditandai dengan kemampan anak membuat kaliamat lebih dari dua kata dan diiringi dengan menyusun kalimat secara sempurna (S-P-O) dan cara pandang anak sudah luas seperti memahami pemikiran dan perasaan orang lain. 
Journal Indonesian Language Education and Literature Vol.1, No. 2, 2016

http://www.syekhnurjati.ac.id/jurnal/index.php/jeill/

Misalnya: "Mamah saya mau kencing, "Papah sedang marah sama saya".

c. Periode Differensiasi (Usia 2,5 - 5 Tahun)

Periode diferensiasi ialah suatu periode yang ditandai dengan dengan kemampuan anak untuk menguasai bahasa sesuai dengan hukum tata bahasa yang baik. Pada saat berkomunikasi dengan orang lain sudah menggunakan tata bahasa yang sempurna yaitu Subjek, Predikat, dan Objek (S-P-O). Perbendaharaan kata sudah berkembang sangat baik secara kualitas maupun kuantitasnya.

\section{B. Metode Penelitian}

Penelitian ini merupakan penelitian deskriptif analisis. Tempat penelitian di Desa Kaliwedi Kidul Kec.Kaliwedi Kab.Cirebon RT 002 RW 001. Populasi 35 anak sedangkan sampelnya 15 anak. Data diperoleh melalui observasi dan wawancara selama empat kali pertemuan. Validitas data dengan menggunakan triangulasi metode dan sumber data. Teknik analisis data menggunakan deskriptif analitik.

\section{Hasil dan Pembahasan}

Hasil pengamatan dari tanggal 30 April s/d 22 Mei di Desa Kaliwedi Kidul Kecamatan Kaliwedi Kab.Cirebon dengan Ninjar, Apriliya dan Siti Asiyah sebagai objek penelitian sangat memberikan banyak kesan dan informasi bagi peneliti.

Penelitian dilakukan dua kali dalam seminggu yakni setiap hari sabtu dan minggu. Proses pengamatan dari minggu pertama s/d minggu keempat dilakukan pemberian hadiah pada minggu kedua dan minggu keempat. Hal ini dilakukan untuk menguji kebenaran prinsip dan hukum belajar teori koneksionisme. Hasil dari pelafalan ditulis sesuai dengan runtunan bunyi fonem yang dilafalkan. Adapun hasil dari pengamatan dilapangan dapat dijabarkan sebagai berikut: 
Journal Indonesian Language Education and Literature Vol.1, No. 2, 2016

http://www.syekhnurjati.ac.id/jurnal/index.php/jeill/

1. Minggu pertama (tanpa hadiah)

Proses pembelajaran bahasa kedua dilakukan dengan mengajukan kata "Five"dan "Susu" kepada Apriliya, Ninjar dan Siti Asiyah untuk dilafalkan. Pada percobaan kata "Five"didapat keragaman lafal dan jumlah pengulangan sampai benar dalam melafalkanya. Adapun rinciannya sebagai berikut:

a. Apriliya dengan mudah melafalkan kata "Susu" dan mengulang kata "Five" sebanyak tujuhbelas kali dengan urutan lafal: 1. F/a/i/s 2. F/i/s 3.F/i/v 4.F/i/s 5.F/a/i/s 6.F/i/s 7.F/a/i/s 8.F/i/s 9.F/a/i/s 10.F/i/v 11.F/i/s 12.F/a/i/s 13.F/e/v 14.F/a/i/s 15.F/i/s 16.F/a/i/s 17.F/a/i/v.

b. Ninjar dapat dengan mudah melafalkan kata "Susu" dan mengulang kata "Five" sebanyak limabelas kali dengan urutan lafal: : 1. F/i/s 2. F/i/s 3.F/i/v $\quad 4 . F / i / s \quad 5 . E / f \quad 6 . F / i / s \quad$ 7.F/e $\quad 8 . F / i / s \quad$ 9.F/a/i/s $\quad 10 . F / i / s \quad 11 . F / i / s$ 12.F/a/i/s 13.F/e 14.F/i/s 15.F/i/s sampai limabelas kali lebih Ninjar belum bisa melafalkan dengan benar.

c. Siti Asiyah melafalkan kata "Susu" dengan mudah dan mengulang kata "Five" sebanyak limabelas kali dengan urutan lafal: 1.F/a/i/s 2. F/a/i/s 3.F/a/i/s 4.F/e/v 5.F/a/i/s 6.F/a/i/s 7.F/a/i/s 8.F/a/e/s 9.F/e/v 10.F/a/i/s 11.

F/a/i/s 12. F/a/i/s 13. F/a/i/s 14. F/a/i/s 15. F/a/i/v

2. Minggu kedua (pemberian hadiah)

Proses pembelajaran bahasa kedua dilakukan dengan mengajukan kata "Kerupuk", "Wafer" dan kata "Five kemudian diberikan hadiah kepada Ninjar, Apriliya dan Sitit Asiyah jika mampu melafalkannya dengan benar. Jumlah pengulangan kata "Five" pada minggu kedua sedikit berkurang dari minggu pertama yakni:

a. Apriliya mengulang kata "Five" sebanyak sepuluh kali. Pada kata "Kerupuk" dan "Wafer" Apriliya dengan mudah melafalkannya.

b. Ninjar mengulang kata "Five" sebanyak lima belas kali dan pada kata "Wafer" Ninjar dengan mudah melafalkannya. Pada kata "Kerupuk" Ninjar mengulang sebanyak duabelas kali dengan urutan lafal: 1.K/e/l/u/p/u/k 2. K/u/p/u 3. K/u/p/u-k/u/p/u 4. K/u/p/u 5. K/u/p/u/k 6. 
$\mathrm{K} / \mathrm{u} / \mathrm{p} / \mathrm{u} 7 . \mathrm{K} / \mathrm{u} / \mathrm{p} / \mathrm{u}-\mathrm{k} / \mathrm{u} / \mathrm{p} / \mathrm{u} 8 . \mathrm{K} / \mathrm{l} / \mathrm{u} / \mathrm{p} / \mathrm{u} / \mathrm{k}$ 9. K/u/p/u-k/u/p/u 10. K/u/p/u 11. $\mathrm{K} / \mathrm{u} / \mathrm{p} / \mathrm{u} / \mathrm{k} 12 . \mathrm{K} / \mathrm{e} / \mathrm{r} / \mathrm{u} / \mathrm{p} / \mathrm{u} / \mathrm{k}$.

c. Siti Asiyah mengulang kata "Five" sebanyak sepuluh kali. Pada kata "Kerupuk" dan "Wafer" Siti Asiyah dengan mudah melafalkannya.

3. Minggu ketiga (tanpa hadiah)

Proses pembelajaran bahasa kedua dilakukan dengan mengajukan kata "Kelelawar", "Five" dan "Kerupuk" kepada Apriliya, Ninjar dan Siti Asiyah untuk dilafalkan. Jumlah pengulangan kata "Five" pada minggu ketiga semakin berkurang. Adapun rinciannya sebagai berikut:

a. Apriliya mengulang kata "Five" sebanyak lima kali, kata "Kerupuk tidak ada pengulangan dan kata "Kelelawar" sebanyak sepuluh kali pengulangan dengan urutan lafal: 1.k/e/l/a/w/a 2.k/e/l/e/w/a/r/a/l 3.k/e/l/a/w/a/s $\quad 4 . \mathrm{k} / \mathrm{e} / \mathrm{l} / \mathrm{e} / \mathrm{l} / \mathrm{a} / \mathrm{w} / \mathrm{a} / \mathrm{r} / \mathrm{a} / \mathrm{l} \quad 5 . \mathrm{k} / \mathrm{e} / \mathrm{l} / \mathrm{e} / \mathrm{l} / \mathrm{a} / \mathrm{w} / \mathrm{a} / \mathrm{s}$ 6.k/e/l/e/l/a/w/a/r/a/l 7.k/e/l/e/l/a/w/a/s 8.k/e/l/a/w/a/s 9.k/e/l/e/l/a/w/a/s $10 . \mathrm{k} / \mathrm{e} / \mathrm{l} / \mathrm{e} / \mathrm{l} / \mathrm{a} / \mathrm{w} / \mathrm{a} / \mathrm{r} /$.

b. Ninjar mengulang kata "Five" sebanyak sepuluh kali, kata "Kerupuk" sebanyak duabelas kali dan kata "Kelelawar" sebanyak duapuluh kali dengan urutan lafal: 1.k/e/l/a/l/a $2 . \mathrm{k} / \mathrm{e} / \mathrm{l} / \mathrm{a} \quad 3.1 / \mathrm{a} / \mathrm{w} / \mathrm{a} / \mathrm{s} \quad 4 . \mathrm{k} / \mathrm{e} / \mathrm{l} / \mathrm{a} / \mathrm{w} / \mathrm{a} / \mathrm{s}$ 5.k/e/l/a/w/a/s 6.k/e/l/a/l/a/r $\quad 7 . \mathrm{k} / \mathrm{e} / \mathrm{l} / \mathrm{a} / \mathrm{w} / \mathrm{a} / \mathrm{r} / \mathrm{a} / \mathrm{s} \quad 8 . \mathrm{k} / \mathrm{e} / \mathrm{l} / \mathrm{a} / \mathrm{l} / \mathrm{a} / \mathrm{r}$ 9.k/e/l/a/w/a/r/a/s 10.k/e/l/a/l/a 11.1/a/w/a/s 12.k/e/l/a/w/a 13.k/e/w/a/r/a/l 14.k/e/l/e/l/a/w/a/s 15.k/e/l/e/l/a/w/a/r/a/l 16.k/e/l/a/w/a/r/a/s 17.1/a/w/a/s 18. k//e/l/e/l/a/w/a/r/a/s 19.k//e/l/e/l/a/w/a/r/a/l 20. K/e/l/e/l/a/w/a/r.

c. Siti Asiyah mengulang kata "Five" sebanyak tujuh kali, kata "Kerupuk" tidak terjadi pengulangan dan kata "Kelelawar" terjadi pengulangan sebanyak tujuh kali dengan urutan lafal: 1.k/e/l/a/w/a/s 2.k/e/l/e/l/a/w/a/s 3.k/e/l/e/w/a/r/a/l 4.k/e/l/a/w/a/s 5.k/e/l/e/l/a/w/a/r/a/s 6.k/e/le/l/a/w/a/s $7 . \mathrm{k} / \mathrm{e} / \mathrm{l} / \mathrm{e} / \mathrm{l} / \mathrm{a} / \mathrm{w} / \mathrm{a} / \mathrm{r}$.

4. Minggu keempat (pemberian hadiah)

Proses pembelajaran bahasa kedua dilakukan dengan memberikan hadiah kepada Apriliya, Ninjar dan Siti Asiyah untuk melafalkan kata "Five", "Kerupuk" dan "Kelelawar". Jumlah pengulangan semakin berkurang dari minggu sebelumnya. Adapun rinciannya sebagai berikut: 
a. Apriliya mengulang kata "Five" sebanyak satu kali, kata "Kelelawar" sebanyak dua kali dan kata "Kerupuk" tidak terjadi pengulangan.

b. Ninjar mengulang kata "Five" sebanyak tiga kali, kata "Kelelawar" sebanyak empat kali dan kata "Kerupuk" sebanyak tiga kali.

c. Siti Asiyah mengulang kata "Five" sebanyak dua kali, kata "Kelelawar" sebanyak tiga kali dan kata "Kerupuk" tidak terjadi pengulangan.

Hasil pengamatan yang dilakukan ditemukan kesesuaian hukum dan prinsip belajar teori Koneksionisme yang dicetuskan oleh Edward Thorndike. Hukum dan prinsip tersebut antara lain: 1. Law Of Exercise (Hukum Latihan) 2. Law Of Effect (Hukum Akibat) 3. Hukum Kesiapan dan 4. Pemberian Hadiah sebagai penguat stimulus. Kesesuaian hukum-hukum tersebut dapat dilihat dengan membaca tabel hasil penelitian yang telah dilakukan berikut ini.

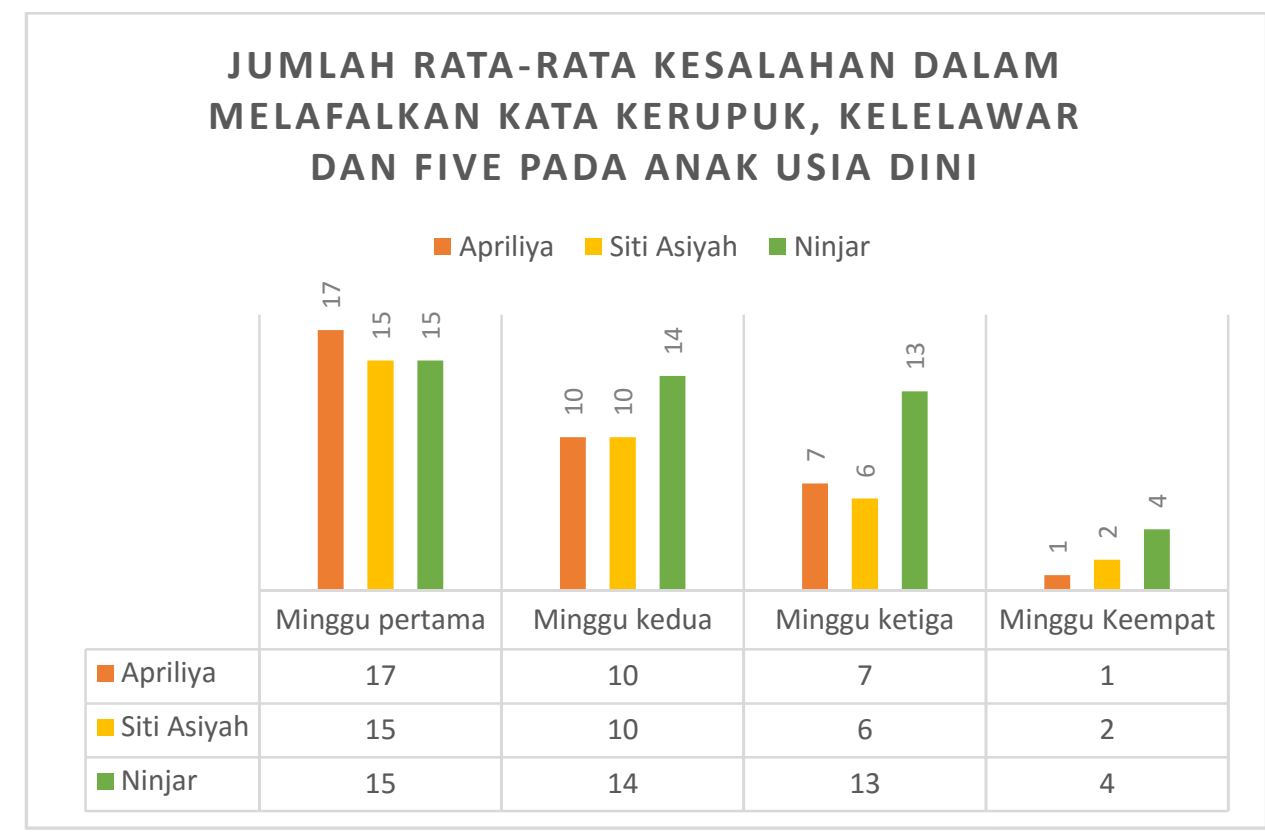

Berdasarkan diagram di atas menunjukan prinsip belajar trial and errordalam teori Koneksionisme dapat terlihat dengan jelas. Semakin Apriliya, Ninjar dan Siti Asiyah melakukan percobaan (trial) dengan mengalami beberapa kegagalan (error)dalam melafalkan selama itu pula proses belajarnya terjadi. Proses belajar ini terlihat pada minggu keempat jumlah kegagalan hanya tersisa sedikit. Hal ini dikarenakan kata yang semakin sering dilatih atau diulang-ulang maka semakin mudah pula kata tersebut ketika dilafalkan. Adapun untuk lebih jelasnya dari data tersebut dapat dianalisis sebagai berikut. 
1. Analisis minggu pertama

Proses pembelajaran bahasa kedua pada minggu pertama menunjukan ketidaksiapan. Hal ini terlihat kata "Five" banyak mengalami jumlah pengulangan yang sangat banyak. Kata "Five" yang merupakan bahasa Inggris menjadi kendala bagi anak-anak dengan latar belakang bahasa Jawa sebagai bahasa ibu.

2. Analisis minggu kedua

Proses pembelajaran bahasa kedua pada minggu kedua sedikit menunjukan kesiapan dari anak-anak. Hal ini terlihat dengan berkurangnya jumlah pengulangan kata "Five". Pemberian hadiah pada minggu kedua menjadi motivasi tersendiri bagi anak-anak untuk secepatnya melafalkan kata "Five" dengan benar. Semua kata selain "Five" yang diajukan dapat dilafalkan dengan benar hanya Ninjar yang tidak bisa. Hal ini dipengaruhi oleh perkembangan bahasa Ninjar yang masih pada periode lingual dini.

3. Analisis minggu ketiga

Proses pembelajaran bahasa kedua pada minggu ketiga semakin menunjukan kesiapan anak-anak dalam belajar. Kesiapan ini terlihat dalam belajar melafalkan kata "Five", "Kerupuk" dan "Kelelawar" anak-anak dengan antusias dan semangat mengikuti ejaan dan cara melafalkannya. Antusiasme dan semangat terjadi karena mengingat minggu sebelumnya anak-anak mendapatkan hadiah.

4. Analisis minggu keempat

Proses pembelajaran bahasa kedua pada minggu keempat kesiapan anak-anak dalam belajar sangat terlihat dan terjadi penurunan yang sangat drastis dalam kesalahan melafalkan kata. Antusiasme dan semangat sangat dirasakan dalam pengulangan kata "Five", "Kerupuk" dan "Kelelawar" dengan cepat dan terburu-buru anak-anak berusaha melafalkannya dengan benar. Kondisi ini dipengaruhi oleh hadiah yang sudah disiapkan sebelumnya. 


\section{Simpulan}

Proses pembelajaran bahasa kedua sangat dipengaruhi oleh faktor usia, bahasa pertama, perkembangan bahasa dan motivasi. Semakin matang perkembangan bahasa pada anak-anak dan semakin motivasinya tinggi maka semakin cepat pula ia menyerap bahasa kedua. Motivasi dalam hal ini adalah pemberian hadiah sebagai stimulus dan respon yang muncul dari anak-anak adalah kepuasan sehingga menjadi penguat anak-anak dalam belajar dikemudian hari. Hukum latihan (Law of exercise) terbukti dapat menunjukan proses belajar dengan semakin sering dilafalkan anak-anak maka akan mengurangi jumlah kegagalan (error) anak dalam melafalkan kata. Pengulangan yang secara signifkan berkurang merupakan law of effect (hukum akibat) dari respon positif yang muncul dalam pembelajaran sehingga dalam melafalkan kata yang diajukan anak-anak cenderung mengulangi terus-menerus sekalipun tanpa diminta.

\section{Daftar Pustaka}

Mulyani, Sri dan Haryanti, Ade Siti. Teori Belajar Bahasa. Tangerang: Pustaka Mandiri.

Dariyo, Agus. Psikologi Perkembangan Anak. (Cetakan ke 2). Bandung:Refika Aditama.

Yusuf, Syamsu. Psikologi Perkembangan Anak dan Remaja. Bandung:Remaja Rosdakarya.

Maulidiyah, Eka Cahya. http://ekacahyamaulidiyah.blogspot.co.id/2014/02/anakusia-dini_6.html. Diakses pada tanggal 15 Mei 2016.

Mahlil, Rahman. http://id.rahmanmahlil.blogspot.co.id teori koneksionisme.html. Dikutip pada pukul 22.30 WIB tanggal 13 Februari 2015.

Tersedia: http://kbbi.web.id/ lafal dan pembelajaran. Diakses pada tanggal $28 \mathrm{Mei}$ 2016. 